Canadian Journal of Applied Linguistics

Revue canadienne de linguistique appliquée

\title{
Tellers, Makers, and Holders of Stories: A Micro-Analytic Understanding of Students' Identity Work in Drama-based Adult ESL Classrooms
}

\author{
Won Kim
}

Volume 24, numéro 3, automne 2021

URI : https://id.erudit.org/iderudit/1084816ar

DOI : https://doi.org/10.37213/cjal.2021.31170

Aller au sommaire du numéro

\section{Éditeur(s)}

University of New Brunswick

ISSN

1920-1818 (numérique)

Découvrir la revue

Citer cet article

Kim, W. (2021). Tellers, Makers, and Holders of Stories: A Micro-Analytic Understanding of Students' Identity Work in Drama-based Adult ESL Classrooms. Canadian Journal of Applied Linguistics / Revue canadienne de linguistique appliquée, 24(3), 186-206. https://doi.org/10.37213/cjal.2021.31170

\section{Résumé de l'article}

Sur les plans académique et pédagogique, l'art dramatique est reconnu comme offrant de nombreuses possibilités de créer des expériences d'apprentissage stimulantes, multimodales et appropriées au contexte (Piazzoli, 2018; Stinson \& Winston, 2011). Cependant, peu d'études empiriques se sont penchées sur les dynamiques interactionnelles en langue seconde dans des cours pour adultes. Cet article présente donc une microanalyse inductive d'un cours d'anglais langue seconde (ALS) au Canada, dans une classe composée de 16 apprenants adultes. Ce cours visait l'exploration du potentiel et de l'impact réel de l'art dramatique sur les interactions et sur l'expérience d'apprentissage d'une langue seconde. Suivant une approche basée sur l'analyse de discours (Antaki \& Widdicombe, 1998; Goffman, 1981), j’analyse le processus dynamique de construction identitaire des participants. Les résultats présentés dans cet article, basés sur des données empiriques d'interactions en classe, montrent comment une pédagogie de l'ALS fondée sur l'art dramatique contribue au développement d'un discours de classe démocratique et axé sur le dialogue. Une telle pédagogie encourage aussi la création d'un espace interpersonnel transformateur et valorisant (Cummins, 2011).
Copyright (c) Won Kim, 2021

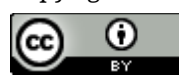

Ce document est protégé par la loi sur le droit d'auteur. L'utilisation des services d’Érudit (y compris la reproduction) est assujettie à sa politique d'utilisation que vous pouvez consulter en ligne.

https://apropos.erudit.org/fr/usagers/politique-dutilisation/ 


\title{
Tellers, Makers, and Holders of Stories: A Micro-Analytic Understanding of Students' Identity Work in Drama-based Adult ESL Classrooms
}

\author{
Won Kim \\ University of British Columbia
}

\begin{abstract}
Despite a wide-spread pedagogical interest and scholarly conviction in the possibilities of educational drama for creating more contextually-situated, engaging, and multi-modal L2 learning experiences (Piazzoli, 2018; Stinson \& Winston, 2011), there is scarce empirical evidence concerning what is actually taking place interactionally in L 2 classrooms for adults. This article presents a bottom-up microanalysis of classroom interaction in an ESL class in Canada with over 16 adult learners designed to explore the potential and actual impact of educational drama on classroom discourse and students' L2 learning experiences. Using a discourse analytic approach (Antaki \& Widdicombe, 1998; Goffman, 1981), I analyze the dynamic identity work of the class participants. The article presents empirically-grounded research findings that illustrate instances of interaction in and through which drama-based ESL pedagogy contributes to the development of dialogic and democratic classroom discourse and fosters a transformative empowering interpersonal space (Cummins, 2011).
\end{abstract}

\section{Résumé}

Sur les plans académique et pédagogique, l'art dramatique est reconnu comme offrant de nombreuses possibilités de créer des expériences d'apprentissage stimulantes, multimodales et appropriées au contexte (Piazzoli, 2018; Stinson \& Winston, 2011). Cependant, peu d'études empiriques se sont penchées sur les dynamiques interactionnelles en langue seconde dans des cours pour adultes. Cet article présente donc une microanalyse inductive d'un cours d'anglais langue seconde (ALS) au Canada, dans une classe composée de 16 apprenants adultes. Ce cours visait l'exploration du potentiel et de l'impact réel de l'art dramatique sur les interactions et sur l'expérience d'apprentissage d'une langue seconde. Suivant une approche basée sur l'analyse de discours (Antaki \& Widdicombe, 1998; Goffman, 1981), j'analyse le processus dynamique de construction identitaire des participants. Les résultats présentés dans cet article, basés sur des données empiriques d'interactions en classe, montrent comment une pédagogie de l'ALS fondée sur l'art dramatique contribue au développement d'un discours de classe démocratique et axé sur le dialogue. Une telle pédagogie encourage aussi la création d'un espace interpersonnel transformateur et valorisant (Cummins, 2011). 


\section{Tellers, Makers, and Holders of Stories: A Micro-Analytic Understanding of Students' Identity Work in Drama-based Adult ESL Classrooms}

Cummins (2009), an influential educator in Canada, calls for an educational vision among teachers, researchers, and policy makers to transform L2 classrooms into an empowering "interpersonal space where minds and identities meet" and "within which the acquisition of knowledge and formation of identity is negotiated" (p. 45). In this educational vision echoed by many other scholars (Cummins \& Early, 2015; Gibbons, 2004; Lean, 2013; Marshall \& Toohey, 2010; Norton, 2013), such an educational space foregrounds the view that L2 learners should not be seen as passive information recipients, but rather as active meaning-makers or language users. Based on this view, numerous scholars recognize aesthetic, creative, and collaborative educational drama as a powerful vehicle for learning across the curriculum (e.g., Booth, 2005; Dunn, 2016; Fels \& Belliveau, 2008; Heathcote \& Bolton, 1995; O’Neill, 1995; Piccardo \& Galante, 2018; Schewe, 2013; Wagner, 1998). Baldwin and Fleming (2003) speak eloquently to the power of educational drama as a learning medium:

Drama, as a multisensory medium, can provide an experiential structure for exploring text visually, auditorily, and kinesthetically. Its participatory nature motivates and promotes affective emotional learning which is the most easily remembered learning whilst at the same time providing intellectual stimulus. (p. 5)

With its engaging, aesthetic, multi-sensory, and improvisational nature, educational drama has also been well received by teachers and scholars in second language (L2) education as an effective means for creating more empowering learning spaces for language learners (Berriz et al., 2018; Bora, 2020; Even, 2008, 2011; Kao \& O'Neill, 1998; Ntelioglou, 2011; Piazzoli, 2011; Stinson, 2009; Winston, 2004, 2011). Importantly, this pedagogical potential outcome of drama-based approach is closely linked with the dynamic construction and negotiation of identities of students and teachers in classrooms as such socially-accomplished, performative identity work can impact the quality and quantity of students' affective, linguistic, interactional, and aesthetic engagement (Baldwin \& Fleming, 2003; Booth, 2005; Brauer, 2002; Piazzoli, 2018; Roman \& Nunez, 2015; Stinson \& Winston, 2011; Wagner, 1998). That is, these imaginative, dynamic interactive performative experiences should involve active participation from both students and teachers engaged in drama-based classroom activities in a make-believe setting.

Over the past decade, our understanding of the potential and actual impact of drama-based instructional experiences on L2 learning has been expanded with the blossom of research studies particularly in reference to the role of drama in the development of oral communicative competence (e.g., Dodson, 2002; Galante \& Thomson, 2017; Gill, 2013; Miccoli, 2003; Stinson \& Winston, 2011) and affective learning involving confidence, motivation, and anxiety as L2 users (e.g., Atas, 2015; Bournot-Trites et al., 2007; Early \& Yeung, 2009; Galante, 2018; Goksel, 2019; Sağlamel \& Kayaoğlu, 2013), and this has significantly informed scholarly and pedagogical discussions on the use of educational drama in L2 classrooms. Nonetheless, there is still a dearth of empirical evidence on how students' and teachers' identity work is actually done in a drama-based L2 classroom particularly those for a steadily growing population of adult learners from various backgrounds (e.g., international, transnational, refugee, immigrant, etc.). More empirically- 
grounded investigations of such a question can yield a nuanced and deeper understanding of how using educational drama can affect teaching/learning for adult L2 learners (Belliveau \& Kim, 2013; DICE Consortium, 2010; McGovern, 2017; Piazzoli, 2018). As such, the central purpose of the present article is to contribute to a growing body of research knowledge on the topic by investigating classroom interaction in English as a Second Language (ESL) classes with educational drama to pursue the questions: What actually takes place interactionally during the class in an adult ESL class and how are identities constructed and managed in the unfolding moment-to-moment classroom interaction?

In this article, I will present the findings of a participant-oriented micro-analysis of classroom interaction in and through which students' identity work is done in the dramabased ESL classroom. More specifically, using the Membership Categorization Analysis (MCA) approach (Antaki \& Widdicombe, 1998; Hester \& Eglin, 1997; Richards, 2006) together with participation framework (Goffman, 1974, 1981), I draw attention to the dynamic identity work of the class participants as they interact with one another. In doing so, I aim to empirically illustrate instances of interaction in and through which educational drama-based ESL pedagogy contributes to the development of dialogic and democratic classroom discourse (Kao \& O'Neill, 1998) and fosters a transformative empowering interpersonal space (Cummins, 2009, 2011) in the classroom.

\section{Identity as a Socially Accomplished Phenomenon}

The argument about identity work put forth in this article is rooted in the general ethnomethodological spirit, informed by Garfinkel (1967), construing social life as what and how people understand what goes on in and through interaction in a particular social context which is displayed and accomplished as interactants in the social context of talk employ the linguistic and para-linguistic features of talk (Antaki \& Widdicombe, 1998). In this ethnomethodological and conversational light, identity is conceived as "the set of verbal practices through which persons assemble and display who they are while in the presence of and in interaction with others" (Johnson, 2006, p. 213). That is, identity is understood as an accomplishment (beyond what seems fixed and can be assumed), and it is considered as ever-changing, dynamic, locally constructed, contextually situated, and interactionally negotiated Widdicombe (1998). Additionally, identity is also conceptualized as an interactional resource through which people accomplish interactional goals and social actions in and through talk-in-interaction in the particular social context of its use (Day, 1998; Goffman, 1981; Greer, 2010; Sacks, 1974, 1992). Viewing identity this way, a discourse analytic approach has been adopted to examine classroom interaction and identity work of class participants with an aim to pursue an in-depth investigation into how class participants negotiate, describe, represent, accept, resist, construct, or affirm meanings and identities in and through interaction in which they are engaged in dramabased ESL classes.

\section{Analytical Framework}

Congruent with the conception of identity as a socially accomplished phenomenon, for the analysis of classroom discourse in this article, two micro-analytic lenses have been adopted: Membership Categorization Analysis (MCA) (Hester \& Eglin, 1997) and 
participation framework (Goffman, 1981). A micro-analysis using these approaches can allow a close examination of the identity work done by interlocutors in the unfolding sequences of talk-in-interaction in and through which they employ identity in making meaning of themselves, others, activities, contexts, and the surrounding world (Baker, 2000). Ultimately, such insights can afford an enriched, nuanced, and complex understanding of students' identity work, the nature of classroom discourse, and their impact on students' L2 development. Specifically, MCA and participation framework can provide a unique participant-oriented understanding of how students and teachers in these classrooms participate in the classroom interaction and how it may shape, affect, and contribute to students' L2 development.

Both of these perspectives can complement one another with their own analytic focus. First, Goffman's perspectives on the organization of social interaction and theatrical presentation of self add insight into the dynamic and complex relationships of the speaker and the hearer in a particular social interaction. Goffman (1981) extends a conventional dyadic perspective of participants (i.e., speaker and hearer) in interaction by decomposing them into more specific participant roles in reference to the production format of talk), i.e., the animator who articulates the words, the author from whom the articulated words originate, and the principal who holds authority and commitments to the words). In addition to the production format, participants in interaction are construed in terms of its participation framework which classifies the hearers present in the event of talk into ratified participants (which is further divided into addressed and unaddressed recipients) or unratified (e.g., bystanders, overhearers, and eavesdroppers). With this expanded view of speaker and hearer, Goffman $(1974,1981)$ also recognizes how, in participation in interaction, stances or alignments (footings) are displayed through language use and how participants govern and are governed by the social context they are situated in (frames). Goffman's perspectives have, hence, been adopted with an aim to gain a dramaturgical insight and observation into how the participants take up different aspects of the hearer and speaker in producing a talk in the drama-based ESL class under study.

Despite its unique contributions as an analytic framework in understanding how talk is organized, what was not substantially considered in Goffman's dramaturgical perspectives is the co-constructed and interactive nature of the talk-in-interaction where the hearer and the speaker are situated. That is, theoretically, Goffman seems to conceptualize the hearer and the speaker as a separate entity engaged in an isolated interaction (Goodwin, 2006). In this light, Goffman's analytic approach could be enriched by a bottom-up ethnomethodological analytic approach, such as MCA, to understand identity work and participant orientation in a naturally occurring interaction. This is because MCA highlights the local constructedness of identity categories by locating identity work in the context of a moment-to-moment unfolding interaction and can thus reveal how membership categories are displayed, described, managed, constructed, and resisted in the unfolding sequence of talk-in-interaction. A combination of Goffman's perspectives and MCA can, therefore, describe how talk in interaction is produced as interactants take up different aspects of the hearer and the speaker and orient to certain footings while presenting a detailed bottom-up micro-analysis of social actions and orders achieved through the use of membership categories. By adopting the above discourse analytic approaches, this article represents findings of the bottom-up microanalysis of the question of whether, when, how, and why a teacher and students in an educational drama-based ESL class for adult learners describe and categorize themselves and others in and through talk-in-interaction. 


\section{Context Description}

The present study is part of a larger ethnographic multi-case study of drama-based ESL classes in a private language institute in western Canada. The classroom interaction that has been chosen for close analysis in this article comes from one of four sections of the 16-week long intermediate ESL course that uses improvisational educational drama as a key teaching approach. The class was taught by a highly experienced teacher who had taught the course for over 20 years. One primary learning aim of the course was to develop students' fluency through educational drama, and the class was composed of 16 students with diverse linguistic and ethnic backgrounds including a large number of students from East Asia such as Japan and Korea. The classroom interaction chosen for analysis in this article was taken from one of the major unscripted, improvisational drama-based projects called the Murder Mystery. This improvisational drama-based project ran for two weeks towards the end of the 16-week term. All of the classroom interaction during this dramabased project was observed, audio-recorded, transcribed, and attentively listened to for close analysis.

\section{Analysis: Listening Closely to the Class}

During the final phase of the improvisational murder mystery drama project, the students were engaged with an improvised court trial scene where the class was divided into two groups in an imaginary court trial: prosecution and defence groups. The students as a group had to either defend or accuse an imaginary character named Naomi (a character who had been collectively created by the students during the first phase of the project) by determining whether she was guilty or not of the death of a psychiatrist (who had also been previously imaginatively constructed by the class). Both sides were asked to come up with five witnesses. There was no pre-written script provided by the teacher, but rather the story emerged spontaneously and organically as the students on each side brought in their jointly created witnesses for a series of testimonies. In short, the story was developed as the court trial determining whether or not Naomi had a mental health challenge with a double personality.

The four extracts under analysis in this article came from the first day and last day of the four-day-long court trial scene as part of the entire eight-day drama-based project. The first extract was taken from the beginning of the court trial scene where the defence side with seven students including Aki (speaking as Naomi) discussed how to defend Naomi in her testimony in the ensuing trial that would shortly begin. Then, the subsequent three extracts represent the final testimony scene in which the defence side questioned Naomi (enacted by Aki) and their last witness, Naomi's best friend (enacted by Naka). The transcriptions used in all the extracts can be seen as a reflexive attempt to capture the soundscape of the interaction as it was heard by the researcher (as a participant observerlistener, Antaki \& Widdicombe, 1998; Forsey, 2010; Kim, 2020). The transcription symbols are derived from the Jeffersonian transcription convention (Jefferson, 2004). All the names in the transcripts are represented by pseudonyms. Through the bottom-up microanalyses of the moment-by-moment unfolding interaction displayed in the four extracts, I aim to empirically demonstrate how students' empowered identities as the tellers, makers, and holders of stories were interactionally achieved through dynamic 
footing and categorical work of the class participants in and through the classroom interaction in this particular ESL classroom with educational drama-based pedagogy.

\section{Drama for negotiating affirmed identity (Extract 1)}

((The students [Ss] in the defence group find their seat around a big table for their first discussion/planning to defend Naomi.))

01 Ss: ((shyly laughs))

02 Kona: ((shyly and smiling)) We have to prove she is crazy. Heheh.

03 Ss: Heheh.

04 (4.0)

05 John: ((in a small voice)) Okay.

$06(4.0)$

07 Naka: Mm. ((somewhat hesitatingly and shyly)) What I am thinking is (1.5) she hears 08 (1.5) devil's voice.

09 ((everyone laughs))

10 John: uh?

11 Naka: ((smiling)) Devil's voice.

12 Ss: heheheh.

13 Naka: ((laughing)) And (2.0) I ((shyly laughs)) heheheh.

14 John: She has a mental disease.

15 Naka: Mmm,

$16 \mathrm{Ss}: \mathrm{Mmm}$,

17 John: So (1.0) uh but the mental disease is from that (perhaps pointing at the teacher in

18 front) teacher (1.5) maybe (1.0) uh yah the teacher has done something to her. And

19 that's why she has a mental disease (1.5) yah,

$20(4.0)$

21 Kona: She is afraid of such a sharp things,

22 Aki: Yah yah.

23 Kona: And also (smiling) she has also another mental disease.

24 Ss: $\mathrm{Mmm}$.

25 John: Mm.

26 Mary: So (1.5) when she is alone, she hears somebody talking to her always.

27 John: Hmm.

28 Aki: Uh?

29 Mary: ((turning to Aki)) When you are alone, you hear somebody talk to you.

30 Aki: Ah. Yah yah.

31 Naka: ((in a small voice)) Maybe teacher?

32 ((a few quietly laugh))

33 John: ((perhaps turning to Aki)) How-how did you kill?

34 Aki: How?

35 John: Uh,

36 Aki: Poison?

37 John: Poison?

38 Ss: ((in a small voice)) Poison.

39 John: But it just happened. She didn't make a plan but it just happened.

40 Ss: Uh? 
41 John: She didn't make a plan to kill her.

42 Kona: Uh uh.

43 John: It just happened.

44 Ss: ((understood)) Ah.

45 Kona: But we have to focus on if she is crazy or not,

4610 John: Yeah, but crazy men don't make a plan. It just happened.

47 Kona: $\mathrm{Mmm}$.

$48(2.0)$

49 Mary: Mm (1.0) make poison (1.0) [is kind of-

50 Aki: Okay,] I have] I have a double character.

$51 \mathrm{Ss}$ : ((in a strongly agreeing tone)) Ahh

52 John: ((approvingly)) Okay okay.

53 Aki: Do you make sense?

54 John: Yah. like a Jekyll and Heidi.

55 Aki: Uh yah.

56 Kona: another character?

57 Ss: (laughs))

$58(1.5)$

59 Kona: So, we need another psychiatrist,

60 ((some laugh))

61 John: Then ((perhaps turns to Aki)) you should act,

62 ((everyone laughs again))

63 John: Good Naomi and bad Naomi.

64 Kona: We need another witness who proves that Aki has double character.

65 John: I am Aki's boyfriend and thinks there are twins, good Naomi and bad

66 Naomi, so I thought your sister killed the psychiatrist. ((perhaps looking

67 around the group for agreement)) okay okay?

68 Aki: Okay okay.

69 Kona: This situation needs a very good actress.

70 John: Yeah, it depends on you, you should be a totally different character.

71 Kona: You have to show a different character.

72 ((everyone giggles))

73 Aki: Okay, hahaha.

74 Kona: ((perhaps turning to Yuna)) can you be a psychiatrist? ((perhaps looking at 75 Naka)) Can you be a best friend?

76 John: ((perhaps pointing at Jin)) she can be a teacher.

In this transcribed first group discussion prior to the ensuing first testimony of the pretended court trial, seven students on the defence side put their heads together to create characters and a narrative about Naomi. The discussion begins with hesitation and silence as marked by relatively long pauses and shy laughter (lines 01-06). A temporary silence is broken when Naka (who normally seems less verbal) surprisingly begins the discussion with her suggestion in lines 7-8: "what I am thinking is that she hears a devil's voice." This initiates a seemingly interesting, seamless, and engaging discussion among the members in the group about the insanity of the character that they are supposed to defend in this imaginary, dramatized court trial. By building on and negotiating ideas about Naomi, the group casts Naomi as a mentally challenged person with double personalities while casting 
themselves as acquaintances of Naomi (e.g., her best friend, a teacher, and a psychiatrist).

This collaborative creation of a story about an imaginary character, Naomi, in an as-if world can be seen as done through the dynamic identity work of the students as and competent makers of stories. By attending to the unfolding interactional details of the group discussion (which can be characterized as a group story-making collusion frame in Goffman's terms), we can see how the interactants take up a creative and collaborative story-maker footing. This is demonstrably made evident when Naka explicitly occasions a story-maker category, "what I am thinking," followed by her suggestion "she hears a devil's voice" (lines 07-08). Here, while "what I am thinking" serves its pragmatic role in making a suggestion, it can also be heard as Naka making relevant a predicate of thinking (perhaps as a story-maker). Thinking about the characteristics of a character is a commonly assumed attribute that is attached to and, at the same time, produces the membership category of story-maker.

Important to note is that Naka's utterance was a self-initiated contribution to the task of creating a story and characters for the purpose of performing in the trial scene. That is, although there was no elicitation nor previous contributions by other members in the group (as marked by two occasions of lengthy pauses and shy laughter tokens [lines 0106]) prior to Naka's suggestion in line 07-08 ("What I am thinking is she hears devil's voice"), Naka agentively and voluntarily initiates the process of making a story about Naomi, presenting herself as a story-maker by linking "thinking" (which may be a relevant predicate to the membership category of story-makers) and "I" (presented as a storymaker). This first move in the group discussion sequence was particularly notable, given my accumulative ethnographic understanding of Naka as generally less audible and vocal during the lessons in the classroom. Interestingly, Naka's contribution seemed to be well acknowledged and appreciated by her group as it was immediately responded with pleasant mild laughter tokens and then a subsequent series of the ensuing related suggestions from other group members to frame the story as Naomi having a mental challenge (lines 14-26).

The dynamic identity work of Naka's self-initiated utterance can be explained with reference to Goffman's notion of the speaker (realized in different modes as the animator [delivering/performing the words], the author [originating the words], and the principal [committed to the words]). Naka can be heard as exercising her agency as an "author" and "principal" with the power to create a personal and medical condition for the imaginary character, Naomi. In Naka's utterance in lines 07-08 ("What I am thinking is she hears devil's voice"), Aki, who is referred to as the third person pronoun "she," is cast into a character or ("figure" in Goffman's terms) in the story they are co-creating. In the subsequent turns, the other group members join Naka in taking up the author footing by extending Naka's idea. Such collaborative creation of the story about the figure, Naomi, who will be animated by Aki, maps all the group members into the category of storymaker. This mapping of a story-maker category is audibly extended to and by Aki (i.e., the animator of the figure Naomi) as she also makes an important contribution to the puzzle of how to justify the character Naomi's murder by insanity, by saying: "okay okay I have a double character" (line 50). What is worth noting is that in her utterance, she refers to herself as the figure Naomi by using the first pronoun "I." Her use of the pronoun "I" can be taken as indicative of her participating in the story-making practice as the figure Naomi while, at the same time, speaking simultaneously as the author of the story.

Further in Goffman's terms, importantly, the above negotiation and exchange of ideas for the story about Naomi in this episode can be heard as an example of how all the 
members in the group participate both as ratified hearers (who are acknowledged as legitimate hearers actively listening to what is being discussed and negotiated at the moment) and as the author (who actively speaks with suggestions for the story). Interestingly, Aki's speaker role as the figure (Naomi) is also explicitly occasioned by others in the group when John turns to her and asks using the second person pronoun: "how did you kill her?" (line 33). Also, an orientation to Aki as the figure/animator is jointly indexed when John and Kona jokingly say that Aki should do good acting (lines 6971). All her group members seem to expect Aki to animate (or enact) the figure of Naomi with double characters for the common purpose of winning the as-if competitive court trial they are situated in the classroom for the moment.

The above group interaction makes evident how the production of a narrative(s) about the imaginary character, Naomi, was achieved through students' orientation to one another's story-maker footing, which was made relevant during the interaction in this lesson. The students talked themselves into being the joint story-maker category which was occasioned by its associated predicates, such as thinking (lines 7-8), assigning medical/personal conditions to the character (lines 14-26), casting one another into relevant characters (lines 66-76), to name a few.

What is also worth noting is how the students dynamically shift the speaker roles of animator, figure, author, and principal displayed within this short segment of interaction. In doing so, they freely and swiftly cross the borders of four different worlds: the world that is imagined and narrated (as figures), the story world to be performed (as animators), the world in which they are currently situated in narrating the story about Naomi (as the author and principal), and the world of which they are part in the drama activity (as language learners). In addition to the students' multiple speaker roles crossing the different worlds (or frames in Goffman's terms), another important point to note is that all the participants here seem to recognize one another as ratified hearers who all belong to the MCD (Membership Categorization Device) of L2 education with drama-based pedagogy. As heard in the case of Aki, the students seemed to be recognized as ratified by one another (even when they were not directly and explicitly addressed) as anyone was welcome to take up the speaker's role agentively and voluntarily by exercising their right to speak (Norton, 2013). Even those, such as Jin and Yuna, who are not prominently audible for this moment of interaction are found to display their timely audible contributions with their relevant suggestions and questions in the latter part of the interaction. In and through this constant shift between ratified hearers and multiple speaker roles (as the author, figure, animator, and principal), all the members collaboratively achieved the construction of developing versions of the story about Naomi. Importantly, such a collaborative coconstruction of the story about Naomi by all the students as ratified participants demonstrably occasioned an MCD of a collaborative story-making community in the ESL classroom. Everyone's voice was welcomed, heard, negotiated, and affirmed, which Cummins and Early (2011) argue is an important feature of an empowering learning community in classrooms.

Viewed in this light, important insight can be drawn. It is critical to recognize that a collaborative learning community could mean that all participants in classrooms are affirmed by and affirm one another as ratified participants. Whether they are addressed or unaddressed as audibly witnessed in this classroom episode, in the group discussion in the drama-based ESL classroom, all the students in the group were positioned as ratified, legitimate participants at the moment. In this sense, in drama-based classrooms, one can 
argue that it is possible that participants can all be ultimately all (addressed) ratified participants even when they are seen as unaddressed in spoken interaction. Understood this way, the above episode from this particular lesson in the drama-based classroom empirically describes how a collaborative L2 learning community where the voices of the students as legitimate participants were affirmed and negotiated was interactionally and momentarily achieved as the students engaged in the practice of story-making.

Students' high engagement with the story-making is further evidenced during the actual performed court trial. The following three extracts represent part of the last day of the four-day trial lesson where Naka speaks as a witness for the defence side by enacting a character of Naomi's best friend. Naka is being questioned by a lawyer from the defence side performed by Kona. In response to Kona's question, Naka begins to offer a relatively lengthy account about Naomi (and Reina, who the students in the defence group created as a devil character living in Naomi).

\section{Drama for meaning-making beyond L2 learning (Extract 2)}

01 Naka: ((slowly and calmly)) She said that (0.5) umm (0.3) she said that Reina 02 believes me because I am the best friend of Naomi. Actually Reina like loves 03 loves Naomi, and Reina wants to protect Naomi from doctors because Reina is 04 afraid of sharp things, but doctor (0.5) when doctor tried to tried to cure her, 05 doctor used sharp things, so (1.0) Reina Reina get angry and tried to (0.3) tried 06 to protect Naomi from doctors. So (2.0) mmm, (3.5)

07 Kona: ((stands and speaks calmly and seriously) So can I confirm that (1.5) ummm:::: 08 the (1.0) Naomi and- ah Reina was existed from uh (0.3) kindergarten? [or before09 Teacher: ((corrects Kona's grammatical error)) They existed,] you don't need passive 10 voice $=$

11 Kona: ((sounds somewhat unenthusiastic)) [Yeah hehhh, 12 Teacher: They existed]

13 Kona: So::: Ermmmm::: (1.5) that's a (.) mmm (1.0) the (1.2) many children 14 played role (0.5) [uh plays the (1.0)

15 John: Role play]

16 ((the teacher and a few students also echo role play, immediately after John)) 17 Kona: [Yeah] role play $(0.5)$ was after

The extract begins with the question by Kona concerning the relationship between Naomi and Naka (speaking as Naomi's best friend). Kona's standing posture and calm, serious tone, and orientation to her pretended lawyer footing. In lines 1-6, Naka provides a very detailed, believable, and carefully articulated answer expressed with occasional pauses and a low yet cautious and serious tonal quality, which may index her strong orientation to her pretended witness footing. In doing so, together with other unaddressed ratified participants in the as-if court space, Naka and Kona co-construct what is recognizable as a pretended court trial frame in the drama world for the moment. A closer listen allows an insight into how Naka and Kona establish themselves as belonging to the members of the make-believe court trial world (i.e., as a lawyer and a witness) by occasioning the relevant bound predicates such as Kona's self-initiated standing posture as a lawyer during the testimony (lines 1-16), using contextually-appropriate relatively formal register such as "can I confirm that..." (line 7), providing a lengthy detailed testimony 
(lines 1-6), and attentive listening to one another throughout the testimony. By doing so, their categorical work displays their creativity and cultural competence in constructing the court story world by making relevant predicates associated with the categories of the court trial MCD (e.g., postures, obligations, activities, speaking tonal quality of court trial participants). In terms of Goffman's production format, it can also be claimed that as animators of the figures (i.e., Naomi's best friend and the lawyer respectively), Naka and Kona successfully presented and performed the story they intersubjectively agreed on. In doing so, they presented themselves as the co-authors (as well as the principal) of the emerging story that the entire class had constructed and negotiated over the past four days of the pretended trial.

While engaged in the story-making and telling practice as the animators, authors, and principals in this beginning sequence of the talk, interesting categorical work is done in the subsequent interaction. Following Naka's response, Kona goes on to ask another question in line 7: "Can I confirm that Naomi and, ah Reina, was existed from kindergarten?" This can be heard as her attempt to achieve a clearer intersubjective understanding between herself and Naka as well as with all other ratified hearers in the court drama world. This can also be heard as a rhetorical move to substantiate her upcoming argument that it was from her childhood that Naomi suffered double personality problems. In other words, Kona simultaneously serves as the animator (who speaks the words of the lawyer), the author (who creates a version of the larger story about Naomi), and the principal (who is committed to a version of the story being narrated). In and through her turn, Kona exercises her agency to influence and shape an intersubjective understanding about Naomi and Reina among all involved in the imaginary court trial. Notably, as observed earlier, in animating her figure as a lawyer, she exhibits a strong orientation to her pretended lawyer footing by making reflective and contextually-relevant paralinguistic and linguistic choices in accordance with the frame of a fictional court trial (e.g., she uses a relatively formal phrase, "can I confirm that," while speaking in a calm and firm tone, standing to talk).

In such Kona's believable enactment as a pretended lawyer, what is important to note is that the pretended court trial frame is unexpectedly shifted by the teacher (in a role as a pretended judge) when she interrupts Kona's talk in line 9 in order to correct Kona's grammatical mistake by saying "no, they existed. You don't need passive voice" (lines 910). For the moment, through her other-initiated and other-complete repair (Schegloff et al., 1977), which is a common instructional practice in L2 classrooms, the teacher displays a shift in her footing from a pretend judge to a language instructor. Through this shift in footing by the teacher, temporarily, the omnirelevant MCD of language education is invoked, and the membership of conventional language instructor category and its standard relational pair category namely student are made relevant. Such teachers' spontaneous interruption for recast is often considered a normative teaching practice and teacher script in conventional L2 classroom discourse where a teacher often holds power to manage turntaking practices (see Hellerman, 2011; Kasper, 1985; Nunan, 1989; Seedhouse, 2004; Van Lier, 1988). Nonetheless, Kona does not indicate any appreciative response to the correction.

Conventionally, acknowledging a teachers' oral feedback by either repeating or showing a verbal or non-verbal sign of appreciation is a bound predicate for the conventional learner category (Kasper, 1985; Van Lier, 1988). However, such a learner membership category seems to be rejected here. That is, for the moment, the teacher 
locally occasioned the MCD of a language classroom that normatively values accurate usage of linguistic forms. In doing so, the teacher cast Kona into a language learner category. However, Kona showed her resistance to this momentarily locally occasioned learner category and, instead, interactionally managed to maintain her pretended lawyer category by not uptaking the teacher's recast and correction immediately and rather choosing to continue with her testimony. Consequently, the omnirelevant conventional language instruction frame was not achieved collectively by all the participants, but instead, the frame of pretended court trial was resumed and sustained. This can be taken as evidence for Kona's high engagement with the story-making practice rather than with that of accuracy-oriented language learning. Alternatively, this could also be understood with reference to Goffman's notion of the principal who is committed to his or her words or ideas. That is, Kona's resistance may display her authority and commitment to the ideas and words that she is animating along with her group.

Interestingly, later in the extract, Kona is again interrupted, but this time by her fellow group mate, John, followed by some others in the classroom (lines 15-16), when she appears to struggle to articulate her statement or question, marked by cut-offs, pauses, and hesitations (lines 13-14). This time, she seems to acknowledge and welcome the interruption as indexed by her immediate repetition of what John uttered. This may further suggest her orientation to her pretend lawyer footing and/or to her collaborative storymaker footing.

As discussed above, Kona and Naka's categorical work makes evident how students recognize their identities as fully engaged in the drama activity where they actively participate in making and telling a co-constructed story about the character they jointly created, Naomi. Likewise, students' strong commitment to the story and their high engagement with the authoring practice is demonstrably evident in the following extract taken from the last group discussion before the final testimony of the trial as they raise questions, respond critically and creatively to issues and problems, work collaboratively to solve problems and make decisions and reflect on their learning and their choice of actions.

\section{Drama for collaborative story-making (Extract 3)}

((The class just finished the testimony of Naka. The teacher is giving an instruction while the students start talking among themselves.))

01 John: ((jokingly, to Aki)) When did you kill three times heh? They made

02 another victim.

03 ((the other students and the teacher are talking))

04 SS: [heheheh

05 Kona: ((talking to Aki)) I don't know about her past]

06 John: ((talking to someone)) [Can you make another ( )]

07 ((students' laughters in the background)) SS: hehe

08 Teacher: ((talking to both sides)) [Two more witnesses, which is a witness for you

09 and a witness for them, which is Naomi herself So ((turning to Naka)) you may step

10 down now

11 ((some students whisper))]

12 Teacher: ((talking to Naka)) Well done. ((turns to the defence team)) May I

13 have your witness?

14 John: ((continues talking to someone in the group)) [They make another victim 
15 (inaudible)

16 Kona: ((speaking to Aki)) [This is all about double personality]

17 Aki: ()

18 John: ((welcoming Naka back to her seat)) [Naka, good job

19 Kona: ((talking to Aki)) Just you black out] because of memory lack. Lacking

20 memory, because I am Reina, so she wanted to cure the, but memory lacking.

21 Naka: So does Naomi know about the disease ( )

22 Mary: Mmm.

23 ((Teacher talks to another student in the background.))

24 Ss: (laugh)

25 Yuna: Complicated.

26 Kona: ((laughing and talking to perhaps to Aki)) [Either that's you-

27 John: How about] just she said that sorry and I want to cure=

28 Aki: $=$ Okay

29 John: And just answer (.) answer about our question and then ((glancing at the other

30 group)) their question. Just that you first mention about the sorry and I want to cure

31 my disease.

32 Aki: ((approvingly)) Okay okay.

33 John: [Okay?

34 Aki: Okay.]

As represented in the transcript above, Naka steps down as her testimony finishes, and the teacher makes an announcement about the next procedure: "Two more witnesses, which is a witness for you and a witness for them, which is Naomi herself. you may step down now" (lines 08-10); “Well done. May I have your witness?" (line 12). This indexes her shifting from her pretended judge footing to a facilitator or director of the play within the directing frame (where she momentarily facilitates and directs the procedures of the improvisational play).

This drama direction frame coincides with the group collusion/discussion frame, which is considered by Goffman (1981) as backstage talk. What is interesting is how the students immediately shift from the drama character/court audience footings (i.e., animators) to collaborative story-maker footing (i.e., authors) again within the frame of group collusion and discussion. This backstage talk or underlife script (which is often considered as irrelevant to official talk) (Goffman, 1981; Guetierrez et al., 1995) by the students is not irrelevant to the official talk by the teacher that goes on in the classroom. In fact, it is closely related to the official talk. As demonstrated in the extract, without hesitation and teacher's guidance/direction, the students on the defence team (including Aki, Kona, Naka, John, Mary, and Yuna) immediately and voluntarily resume their attention back to their group discussion to work out a testimony for Naomi who is scheduled to speak in the next few minutes as the last speaker of the entire court trial. This is indexed by their being less attentive to the teacher's ongoing announcement. Instead of attending to the teacher, John rather goes on to make comments related to Naka's testimony (lines 1 and 14) and welcomes Naka (line 18) while at the same time Kona and Aki are engaged in discussing Aki's upcoming testimony amongst themselves (lines 5-20).

Halfway through the interaction (lines 19-34), every member in the group resumes their attention back to the group discussion as they shift immediately to a collaborative story-maker footing as their leading lawyers, Kona and John, make suggestions with 
regards to the next testimony of Naomi (performed by Aki). They collaborate to work out the testimony of Naomi, which the students know will be critical to the final judgement. Aki, as an addressed ratified hearer, is carefully attending to what others say to make sure she understands well enough what the whole group jointly produces regarding the murder mystery story. In lines 16 and 19-20, Kona makes a suggestion that the story is all about Naomi's double personality (as Naomi and Reina) and thus Naomi would not need to remember anything about what Reina had done to Naomi. In lines 27 and 29-31, John makes a specific suggestion that Aki should just answer during the ensuing testimony that she is sorry about what happened and that she should answer "yes" if he (in a role as a pretended lawyer) later asks the question, "do you want to be cured?" As indexed by her immediate response in a small yet firm tone (lines 28, 32, and 34), Aki attends carefully to what the group suggests to her as the animator of the figure, Naomi, which may suggest her orientation to a respectful and collaborative group participant category (who understands the vital role that she would play as the animator of a particular figure of Naomi that the group is co-creating).

Viewed from membership categorical work perspectives, students' engagement with collaborative story-making is demonstrated more evidently as their cooperative story maker category membership is used, occasioned, and reinforced during this group discussion on this last day of the four-day improvised court trial. Specifically, the collaborative story-maker category is exhibited in and through the predicates, such as being able to critically identify the thematic nature of the narrative about Naomi with double personality issues (line 16), self-initiated questions and self-motivated suggestions (lines 21-31, by Naka, Kona, and John), encouraging and acknowledging Naka's successful telling of the jointly constructed story (line 18), Aki's determined and firm agreement with the group accompanied with attentive listening (lines 28-34), and joint self-guided group discussion without the teacher's intervention. Importantly, this categorical work contributes to the display and construction of students' identities as both competent and collaborative drama participants engaged in making and telling a believable story for the common purpose of winning the imaginary court trial.

Students' close engagement with the collaborative story-making/telling practice culminates in the final moment of the court trial scene with the last testimony of Naomi (performed by Aki). The analysis below will demonstrate that this time, importantly, the students' identity work is extended in a way that the students position themselves and are positioned as not only collaborative story-makers/tellers but also those that are agentive and creative. As witnessed in the previous episode (extract 3), the defence side has jointly co-constructed the particular narrative about Naomi for the final testimony, and Aki is now on the stand, animating the figure of Naomi. In what follows, as previously consented by her group (as described in the previous episode), Aki begins answering the pre-planned questions from Kona and John (two lawyers for the defence side). As represented in the transcribed episode below, through her highly dramatic performance as Naomi with double personality disorder, Aki effectively engages all the audience in the court story including the researcher sitting in the corner as an unaddressed participant observer-listener listening closely to what is going on. However, as demonstrated in the transcript of the episode below, what is vital to point out is how the audience was engaged not just because of how well Aki dramatically performed as the animator but more importantly because of how competently she exercised her agency, competence, and creative power to spontaneously (re)construct the story in the unfolding moment-to-moment interaction at hand. 


\section{Drama for Empowering Voice (Extract 4)}

((Aki is sitting at the center for the final testimony of the court trial. The lawyers [John and Kona] from the defence side are asking questions))

01 John: ((standing and talking firmly)) Naomi, do you wanna talk something?

02 Aki: Yeah. ((shily)) Uh.

03 ((some start laughing, followed by some others' laughter. Perhaps this might 04 be a reaction to how Aki looks shy or uncomfortable, answering the question. 05 Alternatively, it might be because of Aki's dramatic performance as Naomi.))

06 Ben: ((laughs loud))

07 Mary: Hahahaha.

08 Ss: ((laugh)) Hahahaha.

09 Aki: ((try to swallow laughter)) First of all, ((in a controlled and reserved tone)) 10 I am very sorry about her death. But umm (2.0) I don't uh- remember anything 11 about this. (1.0) Sometimes (0.7) I lose my memory, so (1.0) I don't know

12 about even acting myself. (2.0) yah.

$13(3.0)$

14 ((there is some laughter, but it is unclear whose laughter is))

15 Teacher: ((turning to the defence side)) You have other questions?

16 Kona: ((stands up)) I think you::: heard about Reina (1.0) this, uh the first time 17 in this trial and how do you feel about Reina now?

18 Aki: ((in a serious and confused low tone)) I'm really confused now

19 Kona: Ermm hm.

20 Aki: becau:::se:::se:: (0.5) I have never met (1.0) Reina, and mm (1.5) So,

21 Kona: Umm,

22 Aki: I don't have idea about this. I am very [confused now.

23 Kona: ((in an empathetic tone)) Mmm] yah.

24 Aki: I (0.5) I can't believe [really

25 Kona: mmm Okay]

26 ((Heavy silence for a few seconds))

27 John: ((talks seriously, standing)) Do you want to cure about your (1.0) disease?

28 Aki: (2.0) Mmm (4.0)

29 ((Kona whispers to someone near her))

30 SS: ((a few small chuckles break the silence)) [hehe]

31 ((some students follow laughing, watching Aki acting. Someone claps))

32 Kona: ((in a small worried tone)) [Don't cry

33 SS: Hehehe]

34 Teacher: ((in a humorously crying, empathetic voice)) You could talk, 35 Aki: No

36 Teacher: You don't want to be cured ((in a tear-filled voice))

37 Aki: ((in a firm tone)) No. mmm.

38 ((some students gasp in surprise))

39 Aki: ((acting in a confused, trembling tone)) I don't know.

40 SS: ((surprised)). Huh?

41 Aki: (in a trembling voice)) I don't ((perhaps looking down)) I don't know

42 Teacher: ((in a genuinely worried tone)) Are you all right? (laughing)

43 Aki: (in a dramatic slightly louder voice) I am not I am not Naomi now. 
44 Teacher: (surprised) Huh.

$45 \mathrm{SS}$ : (surprised) Uh (loud in chorus) uh:::: ohhh:::

46 Teacher: ((in a loud voice)) order ((tapping the table)) order order.

47 SS: ((laugh))

48 Teacher: ((turns to Aki and asks clearly)) Are you Reina?

49 Aki: ((seriously)) I am Reina.

As displayed in the transcribed episode above where Aki (speaking in a role as Naomi) is being questioned by John and Kona (speaking in a role as co-lawyers for the defence team), they all swiftly together (re)produce the pre-negotiated script, which they agreed on in the previous group discussion (as displayed in Extract 3). Aki animates the figure of Naomi as marked by her carefully altered pitch, slow speech, body postures, (dramatically enacted) trembling voice, and lexical and grammatical choices of emotions, attitudes and competence (e.g., I am very sorry; I can't remember; I am confused). Similarly, Kona and John also seem to well display and construct their pretended lawyer category by asking questions in a formal serious manner (e.g., standing posture, asking questions in a confident and unhesitating manner, speaking in a clear calm and firm tone, which are considered as normative predicates bound to their lawyer category) in lines 1 , 16,17 , and 27 . Such ways of interacting can be heard as implicitly categorizing themselves (and also everyone else being momentarily positioned as the audience in the trial) into engaged participant categories bound to the court drama world at play for the moment.

The students' high engagement as the animators (i.e., Naomi and lawyers) in a version of the story about Naomi (to which they are also committed as the principals and co-authors) is clearly further evident when Aki handles the question from John in line 27. Up to this point, Aki seems to successfully reproduce and animate the collectively prenegotiated group's script. This pattern changes when John asks the pre-planned question concerning whether she wants to be cured (line 27). Instead of the collectively prescribed answer "yes," however, after somewhat lengthy hesitation (lines 28-34), she unexpectedly changes her mind and gives a spontaneous answer: "no" (lines 35 and 37). This move startles many others in the drama space. She dramatically reconstructs the narrative about Naomi and changes the direction of the story. By creating her own individual script as the author and principal and performing it as an engaged, believable animator, her category of a competent, agentive, and creative maker, teller, and holder of stories is displayed and achieved for the moment. This individual new script spontaneously created by Aki seems to be interestingly accepted by all the ratified hearers present in the story-authoring world including her defence team as there is no audible sign of interruption or resistance from them but just a rather genuine pleasant surprise audible in line 45. Then, Aki animates her Naomi character footing, creating a believable dramatic performance (i.e. competence and activity bound to an engaged, competent, and creative participant category of the dramabased L2 education MCD).

It is important to point out here that for the moment, it is only Aki who seems to hold the power of creating and telling the story. Demonstrably, the rest of the participants present in the classroom, including the teacher, are not in such a position, being uncertain what will come next. The exercise of such power and authority by Aki can be heard as emergent evidence of her categorical work as an empowered story-maker, teller, and also holder who is competent, confident, and creative. As such an animator and author (as well as the principal for the moment), Aki brings to the climax of the story about Naomi by 
saying in line 24, "I am not I am not Naomi now." Aki's dramatic and creative move further startles all the ratified hearers (including the researcher being genuinely engaged with the spontaneously unfolding story) present in the simultaneously co-occurring multiple worlds (i.e., the court drama world being animated, the story-authoring world being created, and the drama-based language education world in which the students are situated). In crossing these worlds constructed and maintained in and through a moment-tomoment unfolding classroom interaction involving imaginative improvisational educational drama, Aki and her peers' position and are positioned by one another as collaborative, competent, and creative members of multiple worlds of language learning, story, and drama, participating as ratified, empowered storytellers, story makers, and story holders (i.e., the animator, the author, and the principal).

\section{Conclusion}

The purpose of this article was to empirically demonstrate how the interactants in the drama-based ESL classroom displayed, constructed, and cultivated their empowered identities as holders, makers, and tellers of stories. The bottom-up micro-analytic lenses have allowed a nuanced, empirically-grounded, and deeper insight into how the students were interactionally engaged in the meaning-making practices (that were recognizable as a court trial) where they raised questions, made decisions, constructed a cohesive story, attempted to make purposeful and contextually situated lexicogrammatical choices, collaborated together to respond to an issue, questioned critically and creatively, and reflected on their decisions.

This can also be understood with reference to Goffman's notion of different modes of the speaker, which Goffman $(1974,1981)$ states can form the production format of the utterance. The nuanced and locally produced utterances afforded in this classroom can be characterized by many moments of the classes where the students (as the animator) had to deliver and perform the words and stories, that they (as the author) created, and that they were committed to (as the principal). In other words, the students in these classrooms can be heard as belonging to (the MCD of) a creative story-rich drama-based learning community that constitutes and is constitutive of the interplay of three essential parties: the animator, the author, and the principal. This is significant in the L2 experiences of these adult students, because, in many conventional language classrooms especially for adults, it is often normative to observe the positioning of students limited just as passive (and perhaps deficient) animators of words and stories of others; that is, limited as a reader, speaker, or learner of words of those whose voices are often considered as only legitimate (e.g., voices of native speakers of English). The kinds of meaning-making practices that the students were engaged in these classrooms as tellers, makers, and holders of their own words and stories hold important implications for their L2 development as such meaningmaking practices could potentially contribute to the cultivation of students as inquirers (Fels \& Belliveau, 2008), plurilingual meaning-makers (Lin, 2013; Piccardo \& Galante, 2018), or identities of competence (Manyak, 2004) and confidence (Cummins \& Early, 2011, 2015).

Such identity work also has critical implications for L2 classrooms. Drama-based instruction can be conducive to the co-construction and promotion of what Gutierese et al. (1995) called the unscripted third space, which transcends the monologic, dominant teacher script that is often predominantly present in L2 classrooms. The unscripted third space 
brings the convergence of student and teacher scripts. The third space will be filled with both students' and teachers' voices that mediate learning and the curriculum as social practice. After all, it can contribute to building a strong sense of a responsive and productive heteroglossia (Bakhtin, 1986) or dialogic and democratic interaction (Kao \& O'Neill, 1998) in our classrooms where the voices of teachers and students (along with those embedded in class-related texts such as a textbook) co-exist as equally legitimate voices.

From Cummins' point of view, this third space can also be understood as what he calls a transformative interpersonal space where all participants can be empowered in and through dialogic, democratic, and collaborative classroom interaction. Cummins (2009, 2011) emphasizes that it is micro classroom interaction that plays a crucial role in promoting empowerment for students and teachers in our classrooms. In the space with democratic, dialogic, and collaborative classroom interaction, power is collaboratively created and students' identities are affirmed and can grow in dynamic interaction. It is my hope that the findings of the microanalysis presented in this article can be seen as a meaningful addition to our empirically-grounded understanding of how educational drama may afford pedagogical potential for creating and maintaining such a transformative interpersonal space in L2 classrooms. Educational drama may be one powerful of creating an educational space in L2 classrooms that promotes engaging and empowering L2 learning journeys for our students.

Correspondence should be addressed to Won Kim.

Email:won.kim@ubc.ca

\section{Acknowledgements}

I wish to express my gratitude to the reviewers for their helpful, constructive feedback on earlier versions of this article. I also want to thank Genevieve Brisson for her French translation of the abstract.

\section{References}

Antaki, C., \& Widdicombe, S. (1998). Identities in talk. Sage Publications.

Atas M. (2015) The reduction of speaking anxiety in EFL learners through drama techniques. Procedia Social and Behavioral Sciences 176, 961-69.

Baker, C. (2000). Locating culture in action: Membership categorization in texts and talk. In A. Lee \& C. Poynton (Eds.), Culture \& text: Discourse and methodology in social research and cultural studies (pp. 99-113). Rowman \& Littlefield.

Baldwin, P., \& Fleming, K. (2003). Teaching literacy through drama: Creative approaches. Routledge/Falmer.

Belliveau, G., \&Kim, W. (2013). Drama in an L2 classroom: Research synthesis. The Journal for Drama and Theatre in Second \& Foreign Language Education, 7(2), 626.

Berriz, B., Wager, A., \& Poey, V. (Eds.) (2018). Art as a way of talking for emergent bilingual youth. Routledge.

Booth, D. (2005). Story drama: Creating stories through role playing, improvising, and reading aloud. Pembroke.

Bora, S. F. (2020). Curtain up! Enhancing L2 Spontaneous and Authentic Speaking 
opportunities through play scripts and drama-based approaches. RELC Journal. https://doi.org/10.1177/0033688219887536

Bournot-Trites, M., Belliveau, G., Spiliotopoulos, V., \& Seror. J. (2007). The role of drama on cultural sensitivity, Motivation and literacy in a second language context. Journal for Learning through the Arts, 3(1), 1-35.

Brauer, G. (Ed.). (2002). Body and language: Intercultural learning through drama. Ablex Publication.

Cummins, J. (2009). Transformative multiliteracies pedagogy: School-based strategies for closing the achievement gap. Multiple Voices for Ethnically Diverse Exceptional Learners, 11(2), 38-56.

Cummins, J. (2011). The intersection of cognitive and sociocultural factors in the development of reading comprehension among immigrant students. Reading and Writing. http://www.springerlink.com/content/rm482640gtj06346/

Cummins, J., \& Early, M. (2011). Identity texts: The collaborative creation of power in multilingual schools. Trentham Books.

Cummins, J., \& Early, M. (2015). Big ideas for expanding minds: Teaching English language learners across the curriculum. Toronto: Rubicon Press/Pearson Canada.

Day, D. (1998). Being ascribed, and resisted, membership of an ethnic group. In C. Antaki \& S. Widdicombe (Eds.), Identities in talk (pp. 151-170). Sage Publications.

DICE Consortium. (2010). The DICE has been cast. A DICE resource-Research findings and recommendations on educational theatre and drama (Á. Cziboly, Ed.). Budapest, Hungary.

Dodson S. (2002) The educational potential of drama for ESL. In: Brauer G (ed), Body and Language: Intercultural Learning through Drama. Westport, CT: Ablex, 161-80.

Dunn, J. (2016). Demystifying process drama: Exploring the why, what, and how. NJDrama Australia Journal, 40(2), 127-140.

Early, M., \& Yeung, C. (2009). Producing multimodal picture books and dramatic performances in a core French classroom: An exploratory case study. Canadian Modern Language Review, 66(2), 299-322.

Even, S. (2008). Moving in(to) imaginary worlds: Drama Pedagogy for foreign language teaching and learning. Teaching German, 41(2), 161-170.

Even, S. (2011). Drama grammar: Towards a performative postmethod pedagogy. Language Learning Journal, 39(3), 299-312.

Fels, L., \& Belliveau, G. (2008). Exploring curriculum: Performative inquiry, role drama, and learning. Pacific Educational Press.

Forsey, M. G. (2010). Ethnography as participant listening. Ethnography, 11, 558-572.

Galante, A. (2018). Drama for L2 Speaking and Language Anxiety: Evidence from Brazilian EFL Learners. RELC Journal, 49(3), 273-289.

Galante A., \& Thomson R. I. (2017) The effectiveness of drama as an instructional approach for the development of second language oral fluency, comprehensibility and accentedness. TESOL Quarterly 51(1): 115-42.

Garfinkel, H. (1967). Studies in ethnomethodology. Prentice-Hall.

Gibbons, P. (2004). Changing the roles changing the game: A sociocultural perspective on second language learning in the classroom. In G. Williams \& A. Lukin (Eds.), The development of language: Functional perspectives on species and individuals (pp. 196-216). London and New York: Continuum Publishing.

Gill, C. (2013). Enhancing the English-language oral skills of international students through 
drama. English Language Teaching, 6, 29-41.

Goffman, E. (1974). Frame analysis: An essay on the organization of experience. Harper and Row.

Goffman, E. (1981). Forms of talk. University of Pennsylvania Press.

Goksel, E. (2019). Playing with possibilities: Drama and core French in the Montessori elementary classroom in British Columbia, Canada. SCENARIO, XIII(1), 1-20.

Goodwin, C. (2006). Interactive footing. In E. Holt \& R. Clift (Eds.), Reporting talk: Reported speech in interaction (pp. 16-46). Cambridge University Press.

Greer, T. (2010). Identity in interculturality: Using (lack of) cultural knowledge to disalign with an identity category. The Language Teacher, 34(3), 1-7.

Gutierrez, K., Rhymes, B., \& Larson, J. (1995). Script, counterscript, and underlife in the classroom: James Brown versus Brown v. Board of Education. Harvard Educational Review, 65, 445-471.

Heathcote, D., \& Bolton, G. (1995). Drama for learning: Dorothy Heathcote's mantle of the expert approach to education. Heinemann.

Hellermann, J. (2011). Members' methods, members'competencies: Evidence of language learning in longitudinal studies of other-initiated repair. In J. Hall, J.Hellermann, \& S. Pekarek Doehler (Eds.), The Development of Interactional Competence. Multilingual Matters.

Hester, S., \& Eglin, P. (1997). Culture in action: Studies in membership categorization analysis. Washington DC: International Institute for Ethnomethodology and Conversation Analysis, University Press of America.

Jefferson, G. (2004). Glossary of transcript symbols with an introduction. In G. Lerner (Ed.), Conversation analysis: Studies from the first generation (pp. 13-31). John Benjamins Publishing.

Johnson, G. C. (2006). The discursive construction of teacher identities in a research interview. In A. de Fina, D. Schiffrin, \& M. Bamberg (Eds.), Discourse and identity (pp. 213-232). Cambridge University Press.

Kao, S., \& O'Neill, C. (1998). Words into worlds: Learning a second language through process drama. Ablex Publishing.

Kasper, G. (1985). Repair in foreign language teaching. Studies in Second Language Acquisition, 7, 200-215.

Kim, W. (2020). Listening closely to ethnographic experience: Locating researcher identity as participant listener. In P. Iida, T. Reagan, \& J. Schwieter (Eds.). Critical Perspectives on Teaching, Learning, and Society. Readings in Language Studies Book Series, 8, International Society for Language Studies.

Lin, A. (2013). Toward paradigmatic change in TESOL methodologies: Building plurilingual pedagogies from the ground up. TESOL Quarterly, 47(3), 521-545.

Manyak, P. C. (2004). What did she say?": Translation in a primary-grade English immersion class. Multicultural Perspectives, 6, 12-18.

Marshall, E. \& Toohey, K. (2010). Representing family: Community funds of knowledge, bilingualism and multimodality. Harvard Educational Review 80(2), 21-241.

McGovern, K. R. (2017). Conceptualizing drama in the second language classroom. SCENARIO, 27(1), 4-16.

Miccoli L (2003) English through drama for oral skills development. ELT Journal 57(2), $122-129$. 
Norton, B. (2013). Identity and language learning: Extending the conversation (2nd ed.). Bristol: Multilingual Matters.

Ntelioglou, B. Y. (2011). Drama and English language learners. In S. Schonmann (Ed.), KeyConcepts in Theatre/Drama Education (pp. 183-188).

Nunan, D. (1989). Understanding language classrooms. Prentice Hall.

O'Neill, C. (1995). Drama worlds: A framework for process drama. Heinemann.

Piazzoli, E. (2011). Process drama: the use of affective space to reduce language anxiety in the additional language learning classroom. Research in Drama Education: The Journal of Applied Theatre and Performance, 16(4), 557-573.

Piazzoli, E. (2018). Embodying language in action: The artistry of process drama for second language education. Palgrave.

Piccardo, E. \& Galante, A. (2018). Plurilingualism and agency in language education: The role

of dramatic action-oriented tasks. In J.Choi \& S. Ollerhead (Eds.), Plurilingualism in learning and teaching: Complexities across contexts (pp. 147-164). Routledge.

Richards, K. (2006). Being the teacher: Identity and classroom conversation. Applied Linguistics, 27(1), 51-77.

Roman, S., \& Nunez, H. (2015). Drama and CLIL: A new challenge for the teaching approaches in bilingual education. Peter Lang.

Sacks, H. (1974). On the analysability of stories by children. In R. Turner (Ed.), Ethnomethodology: Selected readings. Penguin.

Sacks, H. (1992). Lectures on conversation (Vols. I and II). G. Jefferson (Ed.). Blackwell.

Sağlamel, H., \& Kayaoğlu, M. N. (2013). Creative drama: A possible way to alleviate foreignlanguage anxiety. RELC Journal. https://doi.org/10.1177/0033688213500597

Schegloff, E. A., Jefferson, G., \& Sacks, H. (1977). The preference for self-correction in the organization of repair in conversation. Language, 53(2), 361-382.

Schewe, M. (2013). Taking stock and looking ahead: Drama pedagogy as a gateway to a performative teaching and learning culture. SCENARIO, 7(1), 5-27.

Seedhouse, P. (2004). The interactional architecture of language classroom: A conversation analysis perspective. Blackwell Publishing.

Stinson, M. (2009). Drama is like reversing everything: Intervention research as teacher professional development. Research in Drama Education, 14(2), 225-243.

Stinson, M., \& Winston, J. (Eds.). (2011). Special issue. Drama and second language learning. Research in Drama Education, the Journal of Applied Theatre \& Performance, 16(4).

Van Lier, L. (1988). The classroom and the language learner: Turn-taking. Longman.

Wagner, B. J. (1998). Educational drama and language arts: What research shows. Heinemann.

Weber, S. (2005). Intercultural learning as identity negotiation. Peter Lang.

Widdicombe, S. (1998). Identity as an analysts' and a participants' resource. In C. Antaki \& S. Widdicombe (Eds.), Identities in talk (pp. 191-206). Sage Publications.

Winston, J. (2004). Drama and English at the heart of the curriculum. David Fulton.

Winston, J. (Ed.). (2011). Second language learning through drama: Practical techniques and applications. Routledge. 